\title{
Article \\ The Histone Chaperone HIRA Is a Positive Regulator of Seed Germination
}

\author{
Elodie Layat ${ }^{1, \dagger}$, Marie Bourcy ${ }^{1, \dagger}$, Sylviane Cotterell ${ }^{2}$, Julia Zdzieszyńska ${ }^{3}$, Sophie Desset ${ }^{2}$, Céline Duc ${ }^{4}(\mathbb{D}$, \\ Christophe Tatout ${ }^{2}$, Christophe Bailly ${ }^{1}\left(\mathbb{D}\right.$ and Aline V. Probst ${ }^{2, *}$ (i)
}

1 IBPS, UMR 7622 Biologie du Développement, CNRS, Sorbonne Université, 75005 Paris, France; elodie.layat@gmail.com (E.L.); marie_bourcy@hotmail.com (M.B.); christophe.bailly@upmc.fr (C.B.)

2 iGReD, CNRS, Inserm, Université Clermont Auvergne, 63000 Clermont-Ferrand, France; sylviane.cotterell@uca.fr (S.C.); sophie.desset@uca.fr (S.D.); christophe.tatout@uca.fr (C.T.)

3 Department of Plant Physiology, Institute of Biology, Warsaw University of Life Sciences-SGGW, 02-776 Warsaw, Poland; julia.zdzieszynska@gmail.com

4 UFIP UMR-CNRS 6286, Épigénétique et Dynamique de la Chromatine, Université de Nantes, 2 rue de la Houssinière, 44322 Nantes, France; Celine.Duc@univ-nantes.fr

* Correspondence: aline.probst@uca.fr

+ These authors contributed equally to this work.

Citation: Layat, E.; Bourcy, M.;

Cotterell, S.; Zdzieszyńska, J.; Desset,

S.; Duc, C.; Tatout, C.; Bailly, C.;

Probst, A.V. The Histone Chaperone HIRA Is a Positive Regulator of Seed Germination. Int. J. Mol. Sci. 2021, 22, 4031. https://doi.org/10.3390/ ijms22084031

Academic Editor: Pecinka Ales

Received: 15 March 2021

Accepted: 12 April 2021

Published: 14 April 2021

Publisher's Note: MDPI stays neutral with regard to jurisdictional claims in published maps and institutional affiliations.

Copyright: (C) 2021 by the authors Licensee MDPI, Basel, Switzerland. This article is an open access article distributed under the terms and conditions of the Creative Commons Attribution (CC BY) license (https:// creativecommons.org/licenses/by/ $4.0 /)$.

\begin{abstract}
Histone chaperones regulate the flow and dynamics of histone variants and ensure their assembly into nucleosomal structures, thereby contributing to the repertoire of histone variants in specialized cells or tissues. To date, not much is known on the distribution of histone variants and their modifications in the dry seed embryo. Here, we bring evidence that genes encoding the replacement histone variant $\mathrm{H} 3.3$ are expressed in Arabidopsis dry seeds and that embryo chromatin is characterized by a low H3.1/H3.3 ratio. Loss of HISTONE REGULATOR A (HIRA), a histone chaperone responsible for H3.3 deposition, reduces cellular H3 levels and increases chromatin accessibility in dry seeds. These molecular differences are accompanied by increased seed dormancy in hira-1 mutant seeds. The loss of HIRA negatively affects seed germination even in the absence of HISTONE MONOUBIQUITINATION 1 or TRANSCRIPTION ELONGATION FACTOR II S, known to be required for seed dormancy. Finally, hira-1 mutant seeds show lower germination efficiency when aged under controlled deterioration conditions or when facing unfavorable environmental conditions such as high salinity. Altogether, our results reveal a dependency of dry seed chromatin organization on the replication-independent histone deposition pathway and show that HIRA contributes to modulating seed dormancy and vigor.
\end{abstract}

Keywords: seed dormancy and germination; chromatin; histone variants; histone chaperones; seed vigor

\section{Introduction}

Seeds are central to plant reproduction and the dispersal of plant species, and critical for human nutrition, accounting for approximately $70 \%$ of energy intake of the human population. The seed is a particular developmental stage with low moisture and devoid of metabolic activities including transcription and de novo protein synthesis [1]; this quiescent stage allows survival under unfavorable conditions such as high and low temperatures. Embryo development, triggered by fertilization of egg and central cell, is completed before the seed enters maturation and finally transits to the desiccation phase. The seed's ability to germinate in a wide range of agroclimatic conditions, usually termed as seed vigor, is crucial for seedling emergence and establishment in crop species [2]. Seed vigor results from a complex interaction of seed properties that are affected by genetics, conditions of seed development on the mother plant, seed harvesting processes and conditions of storage after harvest [3]. In addition, an intrinsic biological process, termed seed dormancy, may delay seed germination even when favorable environmental conditions are met [1]. Dormancy 
controls the precise timing of germination to ensure post-germination development of the emerging seedling in appropriate conditions; therefore, diverse environmental signals are integrated to decide when to initiate seed germination [4]. Seed dormancy is mostly controlled by the antagonistic relationship between the plant hormones abscisic acid (ABA), which promotes dormancy, and gibberellins (GAs), which promote germination $[5,6]$. Many molecular regulators of seed dormancy have also been identified so far. They include actors of ABA and GAs metabolism and signaling pathways [6] but also specific genes such as DELAY OF GERMINATION 1 (DOG1), a quantitative trait locus controlling seed dormancy [7].

Exemplified in the model plant Arabidopsis thaliana [8], nuclear and chromatin organization undergo drastic changes during seed development and germination, with dry seeds being characterized by particularly small nuclei with highly condensed chromatin. Starting with the uptake of water during imbibition, the dry and quiescent seed will reactivate metabolism, correlated with an increase in nuclear size and the progressive decondensation of chromatin [8,9]. At the molecular level, germination requires a general re-starting of previously paused protein translation, associated with the degradation of stored mRNAs accumulated during seed maturation $[10,11]$ and down-regulation of dormancy related genes [12]. In the context of the seed, a measured balance between packaging of the large linear DNA molecules into chromatin, which allows protection of the genetic material during seed desiccation, and the control of transcription during maturation is thought to regulate expression of genes involved in dormancy establishment [13]. Seed development is therefore expected to involve chromatin reorganization from nuclear architecture down to changes in the composition and modifications of the basic subunit of chromatin, the nucleosome. The nucleosome allows the first degree of chromatin packaging as $\sim 147 \mathrm{bp}$ of DNA wrap around an octamer of the core histones H2A, H2B, H3 and H4 [14]. Any structural alterations to the nucleosome, such as covalent modifications of histone proteins or the incorporation of different histone variants, can affect the strength of association of histones with DNA and modulate DNA accessibility and higher-order chromatin organization $[15,16]$. Furthermore, combinations of histone post-translational modifications (PTMs), DNA methylation and histone variants contribute to the formation of different chromatin states $[17,18]$. Since transcription requires access to the DNA template and nucleosome disassembly, which can be facilitated or inhibited by different chromatin states, these combinations of epigenetic marks influence local transcriptional outcomes. Chromatin organization is therefore anticipated to contribute to the establishment and maintenance of the dormancy state of the seed. Indeed, mutants lacking several proteins involved in the setting of histone modifications show altered dormancy phenotypes. For example, seeds lacking the H3K9 histone methyltransferases KRYPTONITE (SUVH4/KYP) show increased seed dormancy [19]. Histone deacetylases also contribute to seed dormancy regulation, with HDA9 being a negative regulator of germination [20] while HDA6 and HDA19 contribute to the repression of embryogenic properties and therefore promote germination [21]. Furthermore, mutants in HISTONE MONOUBIQUITINATION 1 (HUB1), an E3 ligase involved in histone $\mathrm{H} 2 \mathrm{~B}$ monoubiquitination, a histone mark associated with transcriptional activity, show reduced seed dormancy [22]. Both histone acetylation and monoubiquitination have the intrinsic capacity to modify the chromatin structure. They interfere with nucleosome-array folding and facilitate DNA accessibility by loosening histone-DNA charge contacts or by modifying the nucleosome structure, respectively [23]. Histone H2B monoubiquitination facilitates transcription elongation and eases nucleosome reassembly [24,25] and its loss leads to lower DOG1 transcript levels in seeds. Altered DOG1 expression was also observed for seeds lacking the TRANSCRIPTION ELONGATION FACTOR II S (TFIIS) / REDUCED DORMANCY 2 (RDO2) [26,27], a component of the RNA Polymerase II transcript elongation complex [28].

At the level of the nucleosome, the co-occurrence of specific histone variants such as the $\mathrm{H} 3$ histone variant $\mathrm{H} 3.3$ and the $\mathrm{H} 2 \mathrm{~A}$ variant $\mathrm{H} 2 \mathrm{~A} . \mathrm{Z}$ can result in unstable nucleosomes [29], and in Arabidopsis, H3.3 occupancy is correlated with RNA pol II association and elevated 
transcriptional activity [30-32]. The correct incorporation of histone variants in time and space depends on evolutionary highly conserved histone chaperone complexes, some of these protein complexes being able to selectively transport or deposit different core histones and even specific histone variants $[16,33]$. In contrast to the replicative variant H3.1, which is assembled into chromatin in a DNA-synthesis-dependent manner, the replacement variant H3.3 is deposited in a DNA-synthesis-independent manner [34]. The CHROMATIN ASSEMBLY FACTOR 1 (CAF-1) complex [35,36] is responsible for H3.1 deposition at the replication fork $[37,38]$ and DNA repair sites [39]. In contrast, H3.3 is deposited through DAXX-ATRX and the HISTONE REGULATOR A (HIRA) chaperone [40,41], which functions in a complex together with UBN and CABIN [42,43]. Mammalian HIRA ensures both de novo deposition and recycling of histone H3.3 [44]. In plants, H3.3 deposition also depends on HIRA [42,43] and ATRX [32] with the HIRA-dependent pathway playing a major role.

While in heterogeneous seedling tissue both $\mathrm{H} 3.1$ and $\mathrm{H} 3.3$ co-exist, with $\mathrm{H} 3.1$ being enriched in heterochromatin and H3.3 at active genes and regulatory regions [30,31,45], certain cell types show preferential enrichment in either H3.1 or H3.3 or in other atypical $\mathrm{H} 3$ variants [46,47]. For example, in root tissues, cells that undergo their last cell division before cell proliferation arrest evict H3.1 and incorporate H3.3 [48]. The absence of H3.1 transcripts and protein have also been observed in mature pollen and no H3.1 protein was found in the egg cell, which expresses high levels of H3.3 [46], together revealing various dynamics of the H3.1/H3.3 balance in different plant tissues.

Here, we show that mostly replacement histone $\mathrm{H} 3$ variants and their deposition machinery are expressed in dry seeds and that embryonic nuclei are enriched in the replacement variant H3.3. Loss of HIRA leads to reduced $\mathrm{H} 3$ histone content and renders dry seed chromatin more accessible to MNase digestion. While hira-1 mutant seeds are viable under standard growth conditions, they show increased dormancy, reduced viability when artificially aged and impaired germination under high salinity, identifying HIRA as a positive regulator of germination.

\section{Results}

\subsection{Dry Seed Chromatin Is Enriched in the Replacement Variant H3.3}

After fertilization, the zygote undergoes cell divisions, forming the embryo before cell proliferation ceases and the embryo matures, building the dry seed. Since the incorporation and exchange of histone variants have been associated with developmental transitions [46,47] or with cells with different proliferation potential [48], we were interested to investigate whether similar changes in the histone $\mathrm{H} 3$ variant repertoire would occur during seed maturation, imbibition and germination. Five genes (HTR1, 2, 3, 9 and 13) encode H3.1, while three genes (HTR4, 5 and 8) encode H3.3. We quantified the transcript levels of these genes in flowers, siliques at different developmental stages of seed formation, dry seeds and seeds imbibed from 2 to $32 \mathrm{~h}$ as well as seedlings two days after germination.

While we found HTR 3 transcript levels to be low at these developmental stages, HTR1, HTR2, HTR9 and HTR13 showed a dynamic expression pattern with high transcript levels in flowers, which strongly decreased during seed maturation and were nearly absent in dry seeds before increasing again modestly $8 \mathrm{~h}$ after imbibition (Figure 1a,b, Figure S1a-c). This expression pattern is similar to that of the FASCIATA 2 (FAS2) gene, encoding the middle subunit of the CAF-1 complex, which is responsible for H3.1 incorporation [9,38]. FAS2 transcripts are undetectable in late silique stages and only present again in germinated seedlings (Figure 1c). 

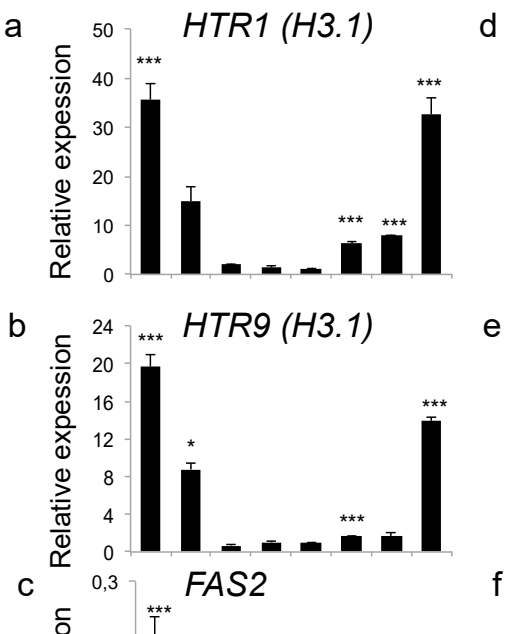

e
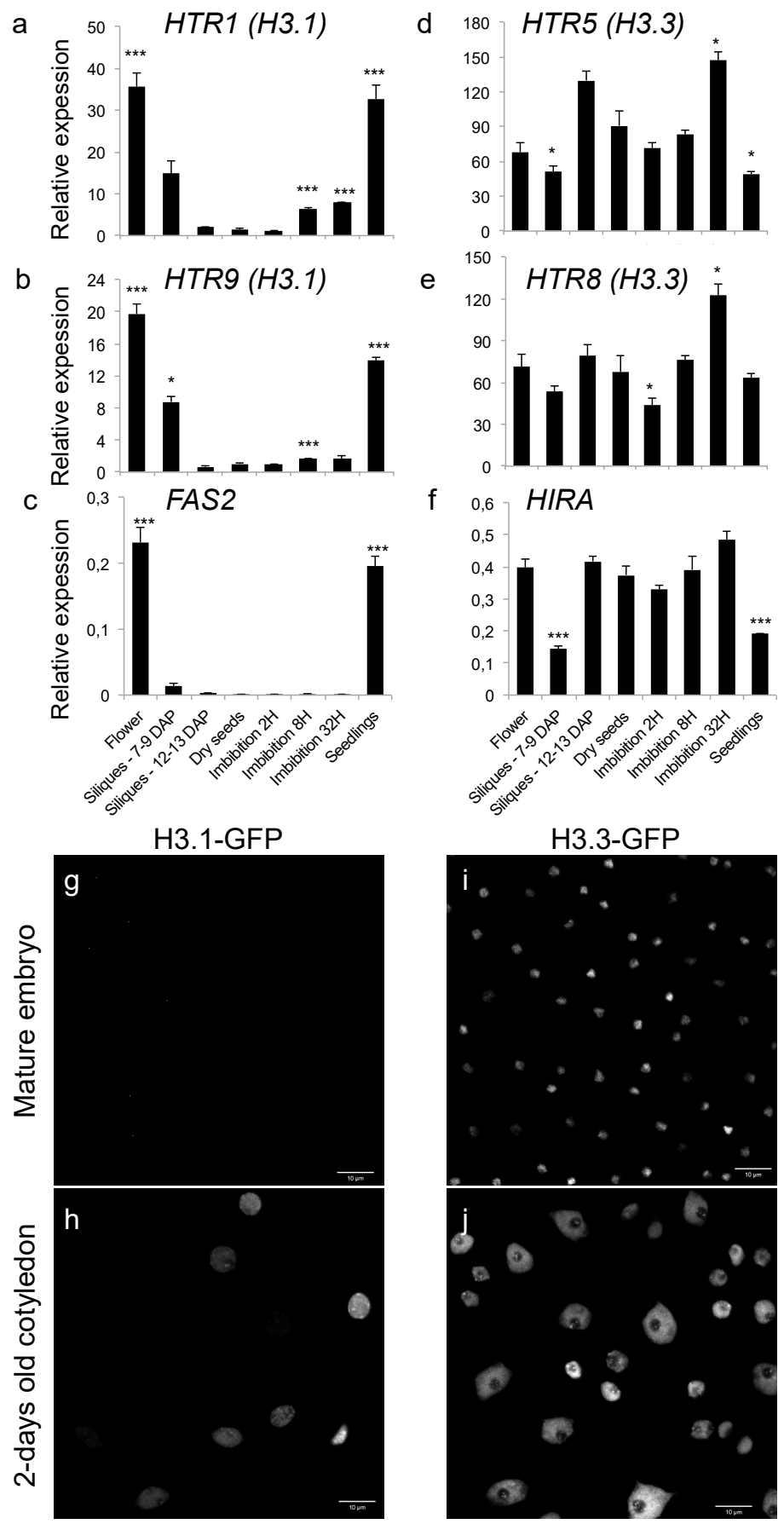

Figure 1. Chromatin in dry seeds is enriched in the replacement histone H3.3 variant. (a-f) Relative transcript levels of two genes encoding H3.1 (HTR1 (a), HTR9 (b)) and the middle subunit of the CAF-1 complex (FAS2 (c)), as well as two genes encoding H3.3 (HTR5 (d), HTR8 (e)) and the central subunit of the HIR complex (HIRA (f)) in flowers, siliques ( 7 to 9 and 12 to 13 days after pollination (DAP)), dry seeds and seeds imbibed for 2 hours (H), $8 \mathrm{~h}$ or $32 \mathrm{~h}$ as well as two-days-old seedlings. Transcript levels are normalized to MONENSIN SENSITIVITY 1 (MON1, At2g28390). Error bars correspond to the standard error of the mean (SEM) of three biological replicates and statistically significant differences relative to dry seeds were determined using a two-sided Student's $t$-test $\left.{ }^{*} p<0.05 ;{ }^{* * *} p<0.001\right)$. (g-j) Maximum intensity projections of confocal images of embryos $1 \mathrm{~h}$ after imbibition $(\mathbf{g}, \mathbf{i})$ and two-days-old cotyledons $(\mathbf{h}, \mathbf{j})$ of transgenic lines expressing H3.1-GFP $(\mathbf{g}, \mathbf{h})$ or H3.3-GFP (i,j). 
In contrast, HTR4, HTR5 and HTR8 (encoding H3.3) as well as the gene encoding the central subunit of the HIR complex (HIRA) are expressed throughout these different developmental stages (Figure 1d-f and Figure S1d) indicating that the H3.3 incorporation pathway is active in maturing and dry seedlings. These expression data are in agreement with published RNA-seq data of dry and imbibed seeds [49] illustrating that the DNA replicationdependent histone deposition machinery as well as most of the H3.1 encoding genes are not expressed in dry seeds (Figure S2a,b), while transcripts of the genes encoding H3.3 or the HIR complex subunits are present at this developmental stage (Figure S2c,d). To confirm these observations at the protein level, we used transgenic plants expressing either H3.1-GFP [50] or H3.3-GFP [46] under control of their endogenous promoters and acquired confocal images of cotyledon nuclei from plantlets two days after germination (dag) and embryos dissected manually from shortly imbibed seeds (Figure 1g-j). While H3.3 is enriched in most nuclei in cotyledons at $2 \mathrm{dag}$, HTR1 (H3.1) is enriched in a subset of nuclei in agreement with previous observations [46,48] (Figure 1h,j). No H3.1-GFP-positive nuclei could be detected in embryonic cotyledons while chromatin of the small and highly condensed nuclei of the embryonic cotyledon was enriched in H3.3 (Figure 1g,i). Thus, chromatin in dry seeds shows a very low $\mathrm{H} 3.1 / \mathrm{H} 3.3$ balance, implying that chromatin dynamics during seed maturation and imbibition rely mostly on the H3.3 incorporation pathway.

\subsection{HIRA Mutant Seeds Show Reduced Histone Content and MNase Hypersensitivity}

The HIRA chaperone complex is the predominant histone chaperone responsible for DNA-synthesis-independent histone deposition in Arabidopsis [32,43]. Nevertheless, hira mutant plants (hira-1) show few developmental defects and are fertile $[42,43,46]$. We could therefore test whether histone levels are affected in hira-1 mutant seeds, a tissue in which only H3.3 gene transcripts are present. We first quantified the transcript levels of genes encoding H3.1 (HTR1, HTR9) and H3.3 (HTR5, HTR8) in hira-1 mutant seeds versus wild type (WT), revealing higher transcript levels of these four histone genes in the mutant background (Figure S3). Despite elevated H3 transcript levels, H3 protein levels in total protein extracts from hira-1 mutant seedlings were lower compared to those in WT seeds (Figure 2a,b), therefore strongly suggesting that in absence of the HIRA-mediated H3 deposition and recycling, seed chromatin shows globally reduced nucleosomal occupancy.

We then asked whether loss of HIRA would lead to altered chromatin organization in seeds. We therefore incubated nuclei isolated from WT and hira-1 mutant dry seeds with micrococcal nuclease (MNase) for different durations. MNase cleaves linker DNA between nucleosome core particles yielding a sequence of DNA fragments down to mononucleosomes. Compared to WT, chromatin from hira-1 mutant seeds was digested more rapidly by MNase revealing increased global chromatin sensitivity to MNase digestion. Together with the reduced histone $\mathrm{H} 3$ content, this suggests that, in the absence of HIRA, H3.3 deposition and recycling cannot be completely ensured by alternative pathways. It further suggests the existence of a different chromatin structure in hira-1 mutant seeds with reduced nucleosomal occupancy and increased chromatin accessibility.

\subsection{HIRA Loss of Function Results in Dormancy Defects}

To reveal the possible functional consequences of altered histone content in hira-1 mutant seeds, we evaluated germination efficiency of these seeds after different stratification times. When placed at $25^{\circ} \mathrm{C}$ in darkness for germination, longer stratification times were necessary to achieve full germination efficiency in hira- 1 mutant seeds compared to WT, revealing increased seed dormancy in hira-1 mutant seeds (Figure 3a). To confirm these results and to ensure that this phenotype is caused by the loss of HIRA, we tested seed dormancy in independent seed batches of WT and hira-1 mutant seeds and included seeds from a complementing line expressing HIRA-GFP under control of its endogenous promoter in the hira-1 mutant background [42]. Freshly harvested seeds of all three genotypes were dormant, as only 5 to $10 \%$ of the seeds germinated at $25^{\circ} \mathrm{C}$ in darkness (Figure $3 \mathrm{~b}$ ). Stratification at $4{ }^{\circ} \mathrm{C}$ for three days increased germination percentages at $25^{\circ} \mathrm{C}$ in darkness 
of WT seeds and seeds from the complementing line to $45 \%$ and $50 \%$, respectively, while only $20 \%$ of hira-1 mutant seeds germinated (Figure 3c). Therefore, the loss of HIRA causes stronger seed dormancy (Figure 3).

a

Col 0

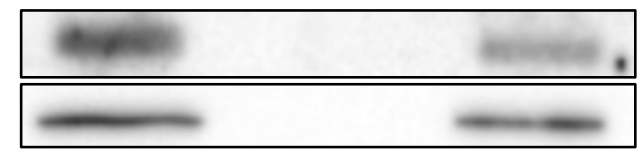

$\alpha-\mathrm{H} 3$ $\alpha-A C T I N$

b

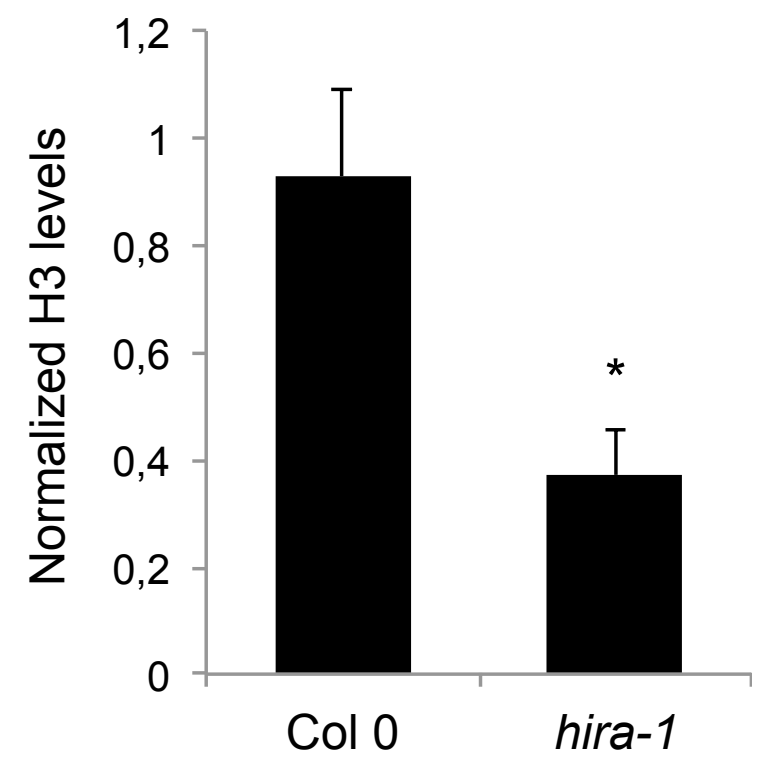

\section{C}

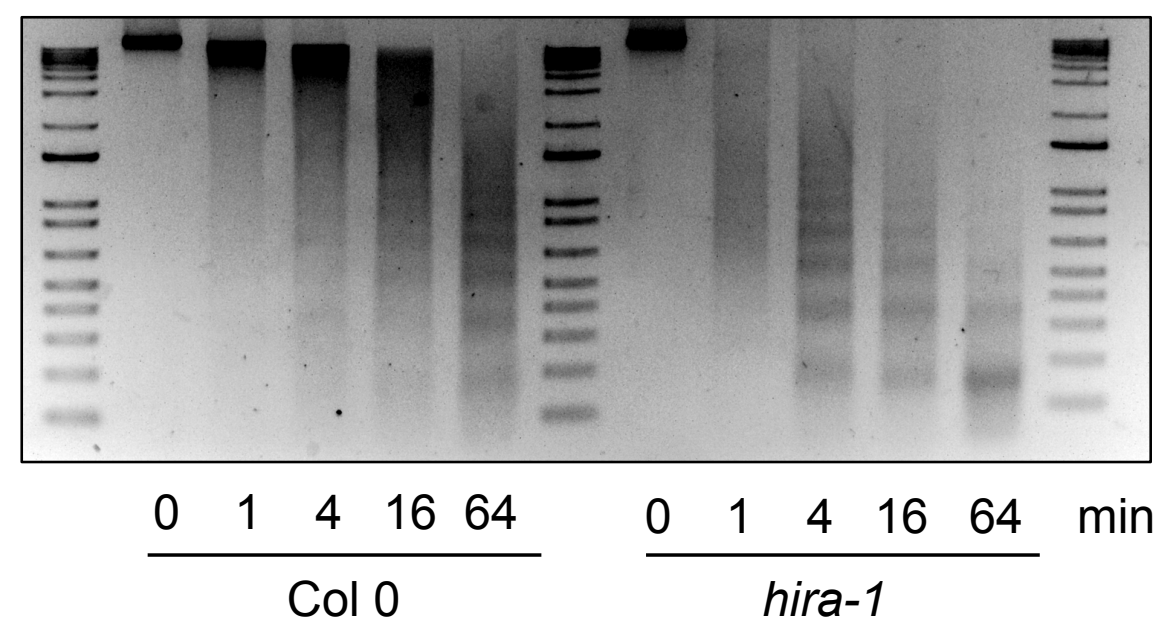

Figure 2. Loss of HIRA leads to reduced H3 content and MNase hypersensitivity. (a) Representative Western blot of H3 histones in total protein extracts from WT and hira-1 mutant dry seeds. (b) Quantification of H3 band intensities relative to ACTIN from three biological and four technical replicates. One wild type sample was set to 1 in each technical replicate. Statistically significant differences relative to WT were determined using a two-sided Student's $t$-test $\left({ }^{*} p<0.05\right)$. (c) Nuclei from WT or hira-1 mutant seeds were isolated and incubated with MNase for 1, 4, 16 and 64 min. Equal amounts of digested DNA were loaded on an agarose gel and stained with ethidium bromide. One experiment of three biological replicates with similar results is shown. 

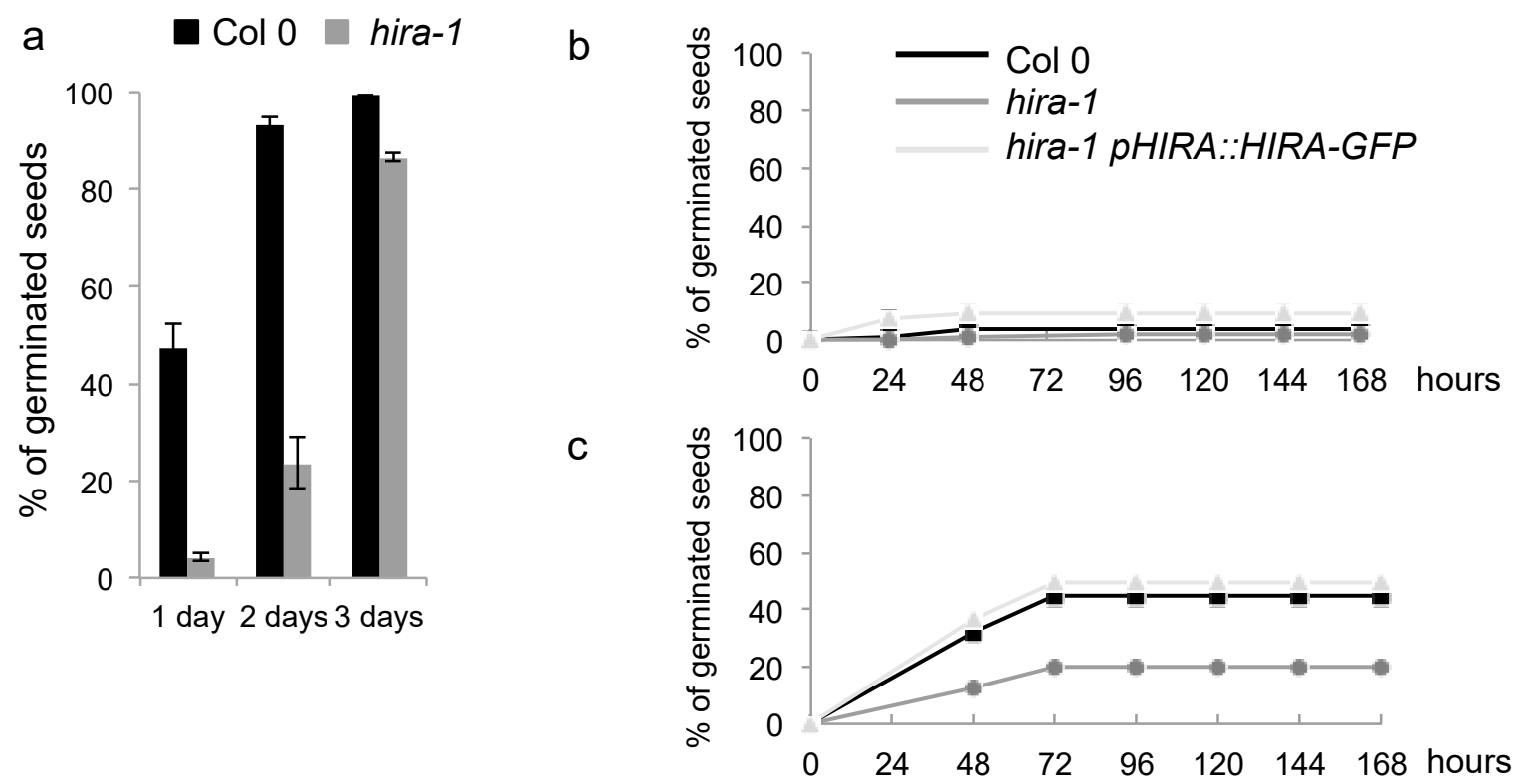

Figure 3. Seeds lacking HIRA show enhanced seed dormancy. Dormancy defects induced by HIRA loss-of-function (a) Germination of freshly harvested seeds of Col-0 (black) and hira-1 mutants (dark grey) in darkness at $25{ }^{\circ} \mathrm{C}$ after one, two and three days of stratification. Percentage of germinating seeds was scored six days after transfer to $25{ }^{\circ} \mathrm{C}$. $(\mathbf{b}, \mathbf{c})$ Germination of freshly harvested seeds of Col-0 (black), hira-1 mutants (dark grey) and the complementing line (hira-1 pHIRA::HIRA-GFP; light grey) in darkness at $25^{\circ} \mathrm{C}$ without (b) and after three days of stratification at $4{ }^{\circ} \mathrm{C}$ (c). Error bars correspond to SD from three biological replicates.

\subsection{Dormancy Defects in hira-1 Mutants Are Unaffected by Plant Hormones}

As dormancy is controlled by plant hormones, with Abscisic acid (ABA) known to promote dormancy, while gibberellin (GA) and ethylene stimulate germination [51], we tested to what extent the increased dormancy phenotype in hira-1 mutants is affected by different plant hormones. When placed at $10{ }^{\circ} \mathrm{C}, 100 \%$ of WT and hira- 1 mutant seeds germinated, confirming seed viability. When grown under the same condition in the presence of $\mathrm{ABA}$, the germination rate of both WT and hira-1 mutant seeds was negatively affected, with a stronger impact on mutant seeds (Figure 4a).

At $25{ }^{\circ} \mathrm{C}$ in the dark, gibberellin and ethylene positively affected the germination of both genotypes, resulting in $100 \%$ germination of the WT batches. While GA and ethylene stimulated the germination of hira-1 mutant seeds, their germination efficiency was lower compared to the WT and only $80 \%$ or $90 \%$ of seeds germinated in the presence of GA and ethylene, respectively (Figure $4 b, c)$, suggesting that the increased dormancy phenotype in hira-1 mutants might be related to lower sensitivity to these dormancyalleviating hormones.

To complement these analyses, we determined transcript levels of several genes involved in ABA, GA and ethylene metabolism in dormant or non-dormant WT and hira-1 mutant seeds before and after incubation for $16 \mathrm{~h}$ or $24 \mathrm{~h}$ under light (Figure S4). No significant differences were observed for genes encoding proteins involved in ABA signaling (ABI5) or catabolism (CYP707A), GA activation (GA3ox1) or catabolism (GA2ox2) and ethylene signal transduction (EIN2), suggesting that hira-1 seed dormancy defects are not caused by the deregulation of expression of these genes. 
a

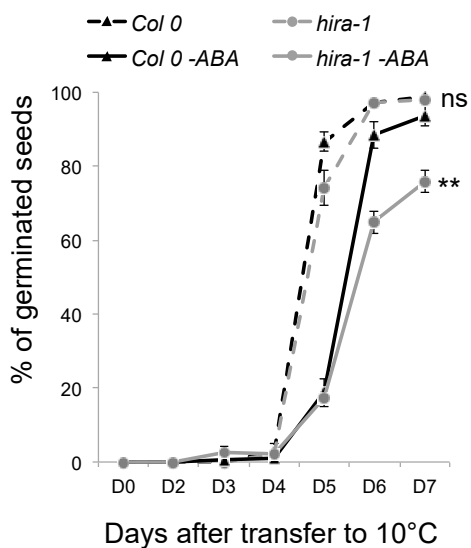

b

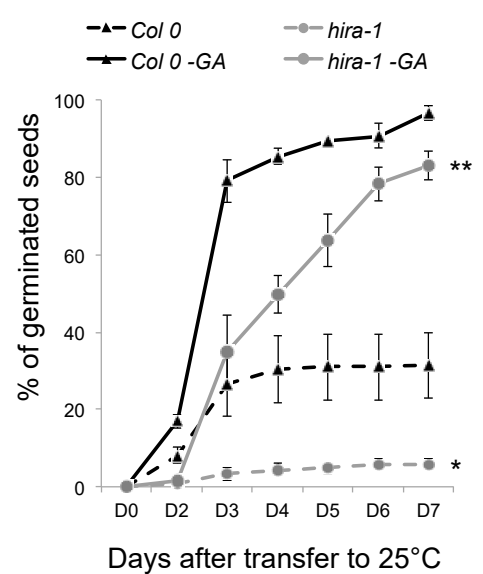

C Ethylene $\left(\mathrm{C}_{2} \mathrm{H}_{4}\right)$

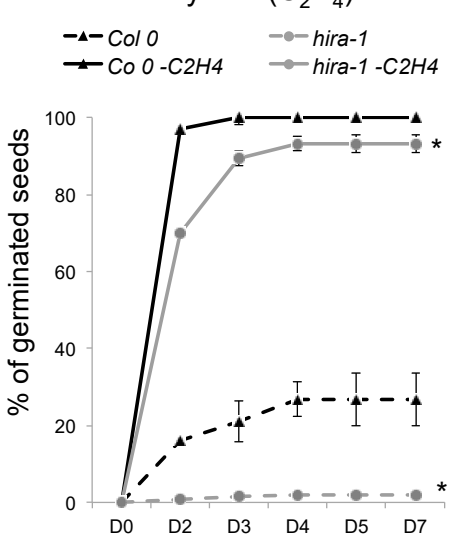

Days after transfer to $25^{\circ} \mathrm{C}$

Figure 4. Enhanced seed dormancy of hira-1 mutants is not alleviated upon treatment with ABA, GA or ethylene. Germination of Col-0 (black, square) and hira-1 mutant (dark grey, circle) seeds in presence (filled line) or absence (dashed line) of $\operatorname{ABA}(1 \mu \mathrm{M})(\mathbf{a})$ at $10{ }^{\circ} \mathrm{C}$ in darkness or of GA $(1 \mathrm{mM})(\mathbf{b})$ and ethylene $(50 \mathrm{ppm})(\mathbf{c})$ at $25^{\circ} \mathrm{C}$ in darkness. Means of biological triplicates with SEM are shown. Statistically significant differences relative to WT at D7 were determined using a two-sided Student's $t$-test $\left({ }^{*} p<0.05 ;{ }^{* *} p<0.01 ;\right.$ ns $=$ not significant).

\subsection{HIRA Counteracts the Positive Regulators of Dormancy TFIIS and HUB1}

Altered histone content in the hira-1 mutant seeds might directly affect gene expression regulation in the dry seed and, consequently, dormancy control. Indeed, a lack of proteins involved in transcription regulation such as RDO2/TFIIS, which is part of the Arabidopsis RNAPII Elongation Complex [28] or RDO4/HUB1, an E3 protein ligase involved in histone H2B monoubiquitination [52], show reduced seed dormancy [22,26,27]. Both have been suggested to facilitate gene expression during late seed maturation stages [53]. To investigate the epistatic relationship between HIRA, TFIIS and HUB1, which all have the potential to affect transcription during seed maturation and germination, we crossed hira-1 mutants to both $r d o 2-2$ and hub1-5 mutants. All double mutant plants were viable and fertile (Figure S5a) and 90 to $100 \%$ of their seeds germinated at $10{ }^{\circ} \mathrm{C}$ (Figure $5 \mathrm{a}$ and Figure S5b).

When placed at $25{ }^{\circ} \mathrm{C}$ in darkness, $r d o 2-2$ and hub1-5 seeds show lower and hira1 mutant seeds higher dormancy levels than WT seeds, as expected (Figure 5b, Figure S5c). Seeds from the double mutants-hub1-5 hira-1 and rdo2-2 hira-1-are more dormant compared to WT. This shows that HIRA is epistatic to RDO2/TFIIS and HUB1 as its absence suppresses the negative effect of $r d o 2$ and hub1 mutants on seed dormancy.

\subsection{Loss of HIRA Reduces Seed Vigor}

Given the reduced histone content and increased MNase sensitivity in hira-1 mutants, we wanted to explore whether these seeds show reduced vigor when germinated in stressful conditions. We therefore first tested germination in the presence of increased salinity, a stress condition known to strongly affect germination [54]. We observed that germination was affected in a dose-dependent manner in the presence of salt in the growth medium. Seeds lacking HIRA germinated less well when exposed to salt. Indeed, $70 \%$ of hira-1 mutant seeds failed to germinate in the presence of $100 \mathrm{mM}$ salt while over $90 \%$ of the WT seeds germinated under these conditions (Figure 6a). 

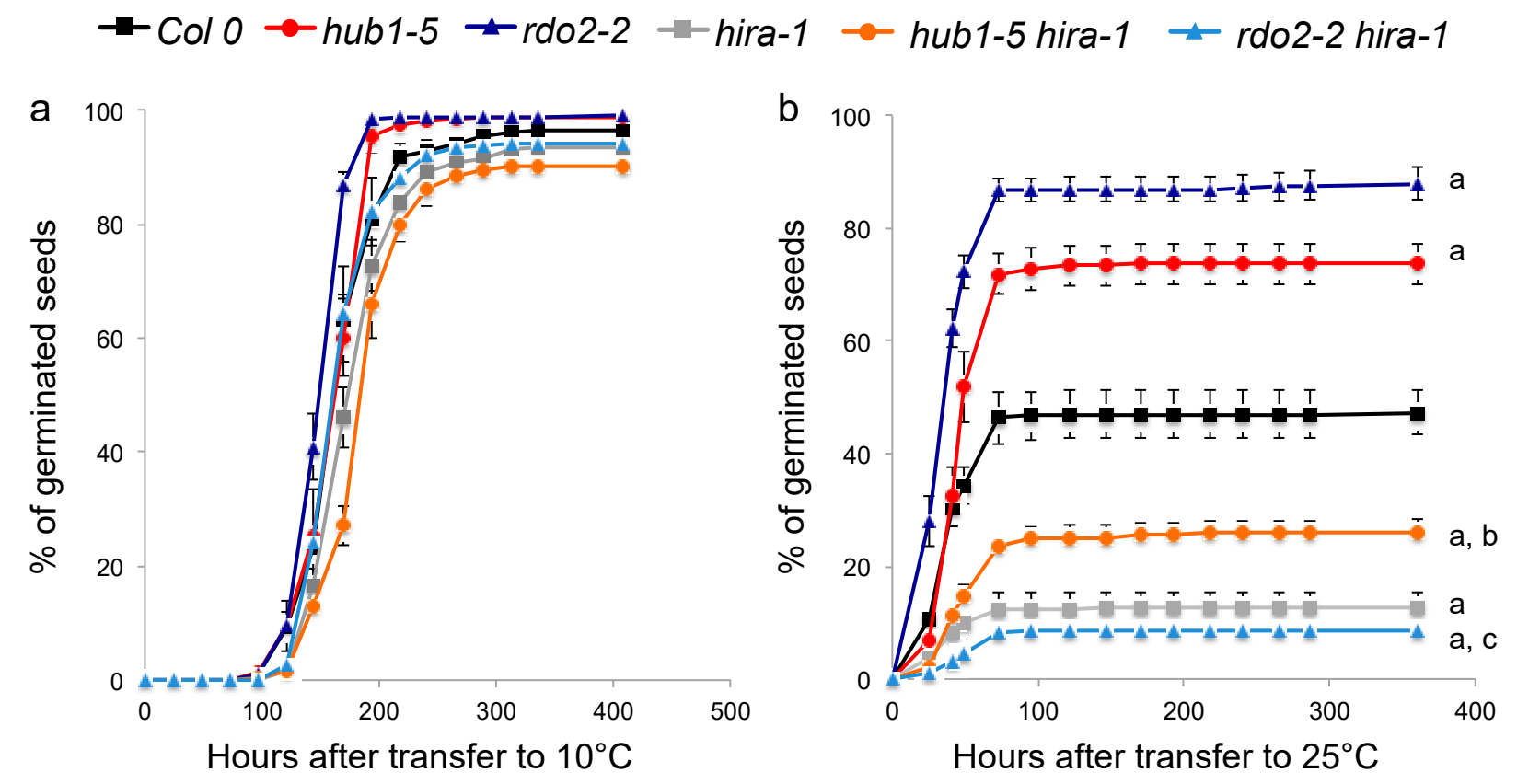

Figure 5. HIRA is epistatic to HUB1 and RDO2/TFIIS. (a,b) Germination of freshly harvested seeds of Col 0 (black), hub1-5 (red), rdo2-2 (dark blue), hira-1 (grey), hub1-5 hira-1 (orange) and rdo2-2 hira-1 (light blue) at $10{ }^{\circ} \mathrm{C}$ (seed viability test; a) or at $25{ }^{\circ} \mathrm{C}$ (dormancy test; $\mathbf{b}$ ) in darkness. Means of biological triplicates with SEM are shown. Statistically significant differences relative to dry seeds were determined using a two-sided Student's $t$-test $(\mathrm{a}=p<0.01$ relative to Col $0 ; \mathrm{b}=p<0.01$ relative to $h u b 1-5 ; \mathrm{c}=p<0.01$ relative to $r d o 2-2$ ).
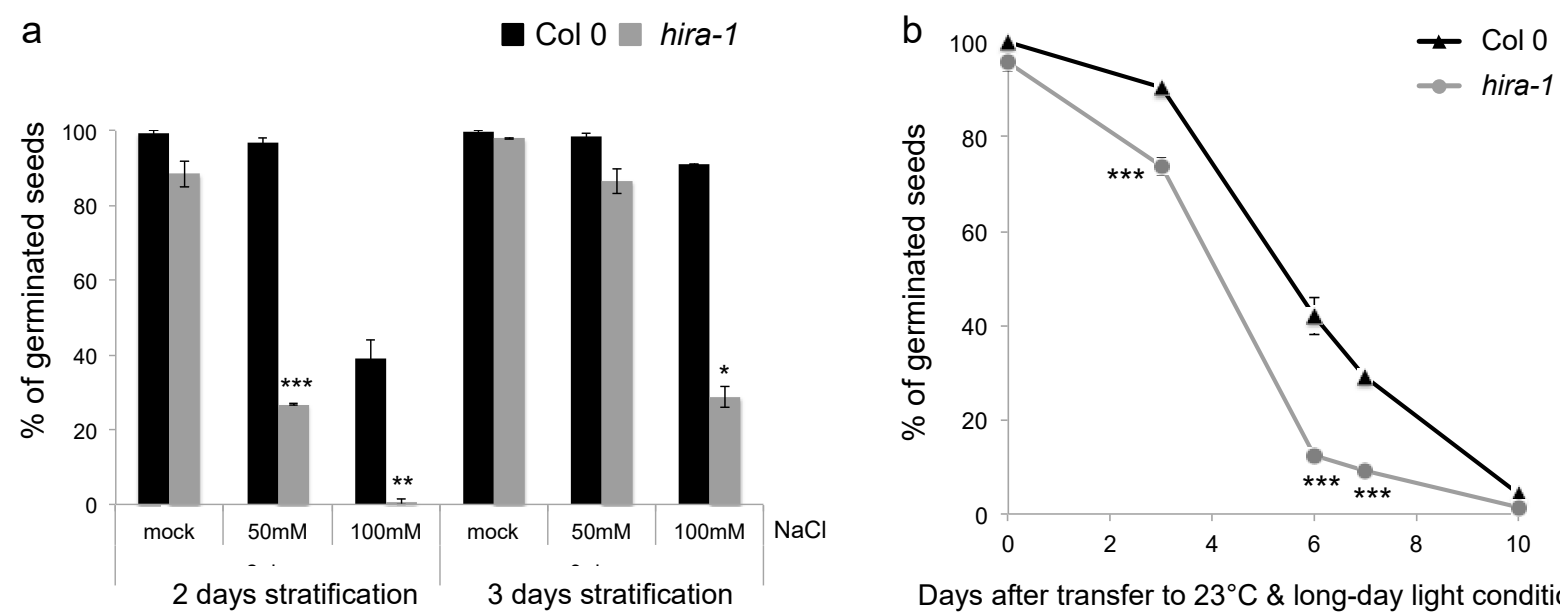

Days after transfer to $23^{\circ} \mathrm{C} \&$ long-day light conditions

Figure 6. Germination of hira-1 mutant seeds is affected by salt stress and is sensitive to storage in a high temperature and humidity. (a) Germination of Col 0 (black) and hira-1 (grey) seeds under long-day conditions at $23^{\circ} \mathrm{C}$ in presence of $50 \mathrm{mM}$ or $100 \mathrm{mM} \mathrm{NaCl}$ after two or three days of stratification at $4{ }^{\circ} \mathrm{C}$ in darkness. Means of two biological replicates with SEM are shown. (b) Germination of $\mathrm{Col} 0$ (black) and hira-1 (grey) seeds under long-day condition at $23^{\circ} \mathrm{C}$ after exposure of dry seeds for $4,6,7$ or 10 days to $80 \%$ relative humidity at $37^{\circ} \mathrm{C}$. Seeds were stratified for three days at $4{ }^{\circ} \mathrm{C}$ in darkness and germinated seeds scored six days after transfer to light. Means of four biological replicates with SEM are shown. Statistically significant differences relative to wild type seeds were determined using a two-sided Student's $t$-test $\left({ }^{*} p<0.05,{ }^{* *} p<0.01\right.$, *** $p<0.001)$.

Then, we tested seed longevity, which is known to rapidly decrease under accelerated ageing treatment (storage under high relative humidity and high temperature). To this aim, we incubated WT and hira-1 mutant seeds in a sealed container with $\sim 80 \%$ humidity for several days at $37^{\circ} \mathrm{C}$ before assessing germination efficiency. While nearly $100 \%$ of both WT 
and hira-1 mutant seeds germinated before the ageing treatment, seeds of both genotypes failed to germinate after 10 days of storage under high temperature and humidity showing the efficiency of this treatment (Figure 6b). At the intermediate time points after four, six and seven days of treatment, significantly fewer hira-1 mutant seeds germinated compared to WT, underscoring the reduced seed vigor caused by the absence of HIRA.

Taken together, chromatin of mature embryos adopts a chromatin state depending on the H3.3 histone incorporation pathway and is characterized by a very low H3.1/H3.3 ratio. In the absence of the HIR complex, the predominant H3.3 incorporation machinery, the $\mathrm{H} 3$ histone content in seeds is reduced and the nuclease accessibility of seed chromatin increased, a molecular phenotype accompanied by the alteration of two important seed traits—seed dormancy and vigor.

\section{Discussion}

\subsection{Embryos in Dry Seeds Have a Particular Chromatin Organization}

Enrichment in histone $\mathrm{H} 3$ variants varies through the cell cycle, with higher levels of H3.1 in S and G2 stages of the cell cycle. Furthermore, a global loss of H3.1 and enrichment in H3.3 was observed when cells completed their last cell cycle before differentiation or switching to the endocycle program $[48,55]$. In the Arabidopsis dry seed, most cells of the embryo are arrested in G1 [56,57]. Only during imbibition, the proportion of 4C nuclei increases in the embryo cell population, resulting from the onset of DNA replication and coinciding with radicle extrusion and therefore completion of the germination process [57]. In agreement with these studies, we observed very low HTR1 and HTR9 transcript levels in mature siliques and dry seeds and detected de novo accumulation of these transcripts during imbibition. In addition, none of the atypical $\mathrm{H} 3$ genes [16,46] are expressed in the seed (Figure S2e). In contrast to H3.1, transcripts encoding the histone H3.3 or HIRA proteins remain high in the dry seed. As a result, chromatin in the embryo shows a low $\mathrm{H} 3.1 / \mathrm{H} 3.3$ ratio. This is not the only peculiarity of the histone variant repertoire in dry seed embryos, as recent reports revealed enrichment of seed chromatin in a particular H2B variant, termed H2B.8 [58,59]. It is interesting to speculate that these different features of seed chromatin contribute to the highly condensed chromatin state and the small nuclei that characterize the dry seed [60]. These specific features may potentially confer desiccation tolerance associated with this quiescent state in orthodox seeds that can survive drying, such as Arabidopsis.

Due to the difficulty of performing chromatin immunoprecipitation on seed chromatin, little information is available concerning the genomic distribution of histone PTMs at the dry seed stage [61]. In leaf tissue, H3.3 is mainly enriched at the $3^{\prime}$ end of transcriptionally active genes [30-32,45] and carries PTMs associated with active transcription [62]. It remains to be explored whether in seeds H3.3 is enriched also in hetero- chromatin or if H3.1 may be retained at certain genomic sites and whether high H3.3 enrichment has repercussions on the PTM landscape. New histone deposition during imbibition and seedling establishment $[57,63]$ may present a window of opportunity to reprogram chromatin structure by incorporating new sets of variants and to set different PTMs [9] to switch from the seed to the seedling transcriptome $[49,64]$.

\subsection{Role of HIRA in Controlling Nucleosome Occupancy and Transcription}

In line with the observation that $\mathrm{H} 3$ supply in the dry seed mostly depends on the H3.3 deposition pathway, we find reduced H3 content and altered chromatin accessibi- lity in hira-1 mutant seeds. Deficient histone recycling and de novo deposition during transcription [44] taking place during seed maturation likely contribute to this phenotype. Indeed, during transcription, chromatin organization is continuously challenged as nucleosomes are displaced and disrupted and histones evicted to allow passage of the RNA polymerase. In mammals, the HIR complex ensures de novo deposition and histone recycling [44,65]. While not all molecular details have been dissected in plants, the composition of the HIR complex is conserved in Arabidopsis [42,43]. The molecular phenotype in hira-1 mutant 
seedlings includes reduced nucleosomal occupancy [43] coherently with our observations in dry seeds. It can be expected that ATRX that is expressed in dry seeds (Figure S2f) contributes to H3.3 deposition [32], but whether atrx mutants also show seed dormancy and germination defects has not been explored yet. Besides HIRA, recycling of H3 histones during transcription is also ensured by the histone chaperones FACT and SPT6 [28]. Mutants in SSRP1, one of the two FACT subunits in Arabidopsis, show reduced seed dormancy [66]. Therefore, even though both FACT and HIRA are involved in histone recycling during transcription and ensure nucleosomal occupancy $[43,44,67]$, their loss has opposite effects on seed dormancy, suggesting that they may differentially impact distinct regions of the genome.

The altered chromatin organization in hira-1 mutants might affect gene expression by facilitating binding of transcription factors through exposure of binding sites, by easing RNA pol II processing through the chromatin template or by causing altered cotranscriptional events such as alternative splicing, which is widespread during germination [64] and influenced by the elongation rate [68]. In addition, reduced nucleosomal occupancy may also negatively affect chromatin state switches from active to repressive chromatin at seed developmental genes.

\subsection{Altered Chromatin Organization in hira-1 Links to Changes in Seed Dormancy}

Seed dormancy is an important trait preventing pre-harvest sprouting and allowing the plant to adjust germination of its seeds to seasonal changes. To achieve this, both intrinsic signals and environmental stimuli need to be integrated to properly time germination. Besides plant hormones [69] and redox signaling [70], gene expression control at the level of chromatin has been shown to regulate dormancy. Many mutants affecting chromatin organization influence dormancy by modulating DOG1 transcript levels. This is the case for $r d o 2$ ( $t$ fIIs) [26] and hub1 mutants [22], which show lower DOG1 transcript levels and reduced dormancy. While we did not observe any difference in transcript levels of genes involved in synthesis and catabolism of the plant hormones ABA, GA and in the ethylene signaling component EIN2 in hira-1 mutant seeds, a moderate increase of DOG1 mRNA was found in hira-1 mutant seeds (Figure S6). Regulation of DOG1 expression may therefore contribute to the increased dormancy phenotype observed in hira-1 mutant seeds, but the exact mode of regulation remains a question for further investigation. Removing HIRA in the rdo2 (tfIIs) and hub1 mutant backgrounds results in seeds that are more dormant than WT. It can therefore be speculated that reduced nucleosome occupancy caused by deficient histone recycling and deposition in the absence of HIRA might facilitate transcription of certain genes. This may in turn lessen the requirement for TFIIS and histone ubiquitination during transcription elongation.

\subsection{HIRA Contributes to Seed Vigor}

In addition to the dormancy phenotype in seeds of hira-1 mutants, we also investigated whether altered chromatin organization could alter seed vigor. This complex trait was assessed by following the ability of mutant seeds to germinate in stressful saline conditions and by their ability to withstand accelerated ageing treatment. The seed vigor of hira-1 mutants is lower compared to WT seeds, which suggests that DNA accessibility can control this trait, with regards to the role of HIRA-mediated histone deposition in transcriptional regulation $[42,71,72]$. Seed germination does not seem to strictly depend on de novo transcription but rather on translation of stored mRNAs [73]. It has nevertheless been proposed that the synthesis of new transcripts during imbibition is required for germination vigor [74] and for adjusting the germination program when seeds face unfavorable stressful conditions, a hypothesis that is in agreement with our observations. In addition, higher sensitivity of hira-1 seeds to accelerated ageing may be a consequence of increased DNA damage. Indeed, cellular damage to macromolecules including DNA occurs during seed storage, for example, through reactive oxygen species [70,75], and is repaired in imbibed seeds $[76,77]$. Due to the failure to properly organize DNA in nucleosomal structures in 
combination with low cellular repair activities in the dry seed, hira-1 mutant seeds may accumulate DNA damage to an extent that renders germination impossible. In line with this hypothesis, HIRA has been shown to play a role in chromatin reassembly after DNA double strand breaks [78] and in transcription recovery after exposure of mammalian cells to UV stress [71].

Seed dormancy and vigor play central roles in the adjustment of plant populations to their environment; however, the molecular mechanisms that integrate environmental signals to define germination timing remain poorly understood. Our work sets another piece to this complex puzzle, revealing a role for the histone chaperone HIRA in controlling histone flow, and consequently, chromatin organization in dry seeds and its contribution to seed vigor and germination under stressful conditions. Further research will show whether HIRA affects the expression of specific genes, alters global transcription efficiency or influences transcript resetting after DNA repair during imbibition. Based on these observations, it will be exciting to explore how enrichment in histone variants and their post-translational modifications is modulated in seed embryos in the field, where seeds face various adverse conditions and undergo multiple rounds of dormancy cycling.

\section{Materials and Methods}

\subsection{Plant Material}

All Arabidopsis thaliana mutant lines are in the Columbia background. T-DNA insertions were obtained from Nottingham Arabidopsis Stock Center (NASC): hira-1 (WiscDsLox362H05), hub1-5 (SALK_044415C) and rdo2-2 / tfIIs-2 (SALK_027259). The hira-1 mutant line complemented by a construct expressing HIRA-GFP under control of its endogenous promoter was a courtesy of F. Berger [42]. Double mutant plants hira-1 hub1-5 and hira-1 rdo2-2 were obtained by genetic crosses. The transgenic lines expressing HTR1-GFP [50] and HTR5-GFP [46] under control of their endogenous promoters were kindly provided by Y. Fang and F. Berger, respectively.

To release physiological dormancy, seeds were stratified at $4{ }^{\circ} \mathrm{C}$ for one to four days before sowing, and plants were grown at $20^{\circ} \mathrm{C}$ under long days (16 h of light / $8 \mathrm{~h}$ of dark). Seeds for germination tests were harvested dormant. To maintain dormancy, seeds were stored at harvest at $-20^{\circ} \mathrm{C}$.

\subsection{Germination Assays}

Dormancy was alleviated by stratification at $4{ }^{\circ} \mathrm{C}$ for different times and germination assays performed at $10^{\circ} \mathrm{C}$ or $25^{\circ} \mathrm{C}$ in darkness in three biological replicates of at least 50 seeds for each genotype in $9-\mathrm{cm}$ petri dishes on a layer of cotton wool covered by a filter paper sheet soaked with water or with water containing $\mathrm{ABA}\left(10^{-6} \mathrm{M}\right), \mathrm{GA}_{3}\left(10^{-3} \mathrm{M}\right)$ or ethylene (50 ppm). Germination was recorded daily, and seeds were scored as germinated once the radicle protruded through the seed coat.

For salinity stress, seeds were sterilized in 70\% ethanol / 0.05\% SDS, washed in 95\% ethanol and sawn on plates with 1x MS medium supplemented with 50 or $100 \mathrm{mM} \mathrm{NaCl}$. For controlled seed deterioration treatment, seeds were incubated at $37^{\circ} \mathrm{C}$ in a sealed plastic container with saturated $\mathrm{KCl}$ solution at the bottom (resulting in air humidity of about $80 \%$ at $37^{\circ} \mathrm{C}$ ) for $4,6,7$ or 10 days, respectively, before being sawn on filter paper. Seeds were stratified for two or three days at $4{ }^{\circ} \mathrm{C}$ and germinated at $20{ }^{\circ} \mathrm{C}$ under long days (16 h of light / $8 \mathrm{~h}$ of dark).

\subsection{Confocal Imaging}

Dry seed embryos from plants expressing HTR1-GFP [50] or HTR5-GFP [46] and cotyledons of two-days-old plantlets from the same seed batch were mounted in $1 \times$ PBS. Dry seeds were manually dissected from seeds imbibed for $1 \mathrm{~h}$ in water. Confocal imaging was performed using a Zeiss Axioimager microscope (Zeiss, Oberkochen, Germany) equipped with a high-speed Yokogawa CSUX1 spinning disk confocal, an ORCA-flash 
4.0 digital camera (Hamamatsu, Hamamatsu, Japan) and a 40X water objective. GFP was excited at $488 \mathrm{~nm}$, and the emission was collected between 500 and $560 \mathrm{~nm}$.

\subsection{RNA Extraction}

Total RNA was extracted from $20 \mathrm{mg}$ of seeds using a modified CTAB method as described by [79]. Alternatively, seeds were ground in liquid nitrogen and taken up in solubilization buffer (100 mM Tris-HCl pH 9,5; $150 \mathrm{mM} \mathrm{NaCl}, 5 \mathrm{mM}$ DTT; 1\% Sarkozyl) followed by phenol-chloroform extraction and precipitation in isopropanol. After precipitation and two washes in 70\% ethanol, RNA was resuspended in water and purified a second time using RNAzol (MRC) according to the manufacturer's instructions. RNA from flowers and two-day-old seedlings were extracted using the RNAzol method only. The RNA concentration and purity were checked using a Nanodrop (Neo Biotech, Nanterre, France).

\section{5. $R T-q P C R$}

A total of $2 \mu \mathrm{g}$ of total RNA was reverse transcribed with oligo(dT)15 using MMLVreverse transcriptase (Promega, Charbonnières, France). cDNAs were diluted 1:3 and used in quantitative PCR with the LightCycler 480 SYBR Green I Master kit on the Roche LightCycler 480. Transcript levels of interest were normalized to MON1 (At2g28390) [80] or to CB5-E (At5g53560), RHIP1 (At4g26410) and TIP41 (At4g34270) [81] using the comparative threshold cycle method. Primers used can be found in Table S1.

\subsection{Western Blot}

Proteins were extracted from about $30 \mathrm{mg}$ of dry seeds in solubilization buffer containing $250 \mathrm{mM}$ Tris- $\mathrm{HCl} \mathrm{pH} \mathrm{7.5,} \beta$-mercaptoethanol $0.07 \%$ and protease inhibitors (Roche), precipitated with TCA $(10 \% \mathrm{v} / \mathrm{v})$ and washed three times in $80 \%$ acetone before being taken up in $2 \times$ Laemmli buffer. Histone H3 was detected with an anti-H3 antibody (dilution 1:3000, ab1791, Abcam, Paris, France,). Immunoblot chemiluminescence was revealed using ECL protein gel blotting detection reagents (Clarity Western ECL Substrate, Bio-Rad, Marnes-la-Coquette, France). Densitometric analysis of immunoreactive protein bands was performed on non-saturated signals using Image Lab software (Bio-Rad, France) and normalized to actin using monoclonal anti-actin antibody (dilution 1:3000, clone 10-B3, A0480, Sigma-Aldrich, Saint Quentin-Fallavier, France).

\subsection{MNase Digestion}

A total of $400 \mathrm{mg}$ of dry seeds were ground to a fine powder in liquid nitrogen and resuspended in extraction buffer $(0.25 \mathrm{M}$ sucrose, $10 \mathrm{mM}$ Tris- $\mathrm{HCl} \mathrm{pH} 8,10 \mathrm{mM}$ $\mathrm{MgCl}_{2}, 1 \mathrm{mM}$ Triton X-100, $5 \mathrm{mM} \beta$-mercaptoethanol and proteinase inhibitors (Roche Diagnostics, Meylan, France). Filtered through miracloth and then through a $40 \mu \mathrm{M}$ nylon filter, nuclei were collected by centrifugation at $1400 \times g$ and then resuspended in MNase buffer $\left(10 \mathrm{mM}\right.$ Tris- $\mathrm{HCl} \mathrm{pH} 7.5,15 \mathrm{mM} \mathrm{NaCl}, 15 \mathrm{mM} \mathrm{KCl}, 1 \mathrm{mM} \mathrm{CaCl}_{2}$ supplemented with proteinase inhibitors). Nuclei extractions were adjusted to $200 \mathrm{ng} / \mu \mathrm{L}$ with MNase buffer after determining DNA concentration with a Nanodrop. Thirty units of MNase (Takara Bio Europe, Saint-Germain-en-Laye, France) were added to a Master tube, containing $300 \mu \mathrm{L}$ of each sample, and $50 \mu \mathrm{L}$ collected at $0,1,4,16$ and $64 \mathrm{~min}$ in $2 \times$ Stop solution (50 mM EDTA, $50 \mathrm{mM}$ EGTA and $1 \%$ SDS supplemented with proteinase K). After incubation for $30 \mathrm{~min}$ at $37^{\circ} \mathrm{C}$, DNA was extracted with CTAB buffer $(2 \%$ CTAB, $100 \mathrm{mM}$ Tris- $\mathrm{HCl} \mathrm{pH} 8,1.5 \mathrm{M} \mathrm{NaCl}$, $20 \mathrm{mM}$ EDTA pH8) and chloroform before precipitation with isopropanol. DNA was taken up in TE buffer (10 mM Tris- $\mathrm{HCl}$ pH 7.5, 5 mM EDTA pH8) and treated by RNAse A / T1 (Thermo Scientific, Villebon sur Yvette, France) for $30 \mathrm{~min}$ at $37^{\circ} \mathrm{C}$. The DNA concentration was determined using a Nanodrop and equal amounts for each sample were run on a $1.5 \%$ agarose gel. 


\section{Conclusions}

In summary, our study sheds light on the chromatin organization in dry seeds, enriched in the replacement histone variant $\mathrm{H} 3.3$. We identify a role for the histone chaperone HIRA in controlling histone $\mathrm{H} 3$ levels and chromatin accessibility in the dry seed. Our results further show reduced seed vigor and enhanced seed dormancy in hira-1 mutants, revealing HIRA as a positive regulator of seed germination. Besides the well-documented role of transcriptional and post-transcriptional mechanisms in this developmental step, our findings therefore highlight the role of epigenetic components in the regulation of the major traits involved in germination phenology. These results open avenues to decipher the contribution of chromatin organization in orchestrating changes in the highly regulated gene expression patterns required for developmental transitions.

Supplementary Materials: The following are available online at https://www.mdpi.com/article/10 .3390/ijms22084031/s1, Figure S1: HTR2, HTR3, HTR13 and HTR4 expression at different developmental stages, Figure S2: Dynamic expression of $\mathrm{H} 3$ histone chaperones during seed imbibition and germination, Figure S3: H3.1 and H3.3 expression in hira-1 mutant seeds, Figure S4: Gene expression in hira-1 mutant seeds, Figure S5: Growth and dormancy phenotypes of single and multiple hira-1, hub1-5 and rdo2-2 mutants, Figure S6: DOG1 expression in hira-1 mutant seeds, Table S1: Primers used in this study.

Author Contributions: Conceptualization, C.B. and A.V.P.; Funding acquisition, C.T., C.B., S.D. and A.V.P.; Investigation, E.L., M.B., S.C., J.Z., S.D., C.D. and A.V.P.; Methodology, E.L., M.B., S.C., S.D. and A.V.P.; Project administration, C.B. and A.V.P.; Supervision, C.D., C.B. and A.V.P.; Writing-original draft, A.V.P.; Writing-review and editing, C.D., C.T., C.B. and A.V.P. All authors have read and agreed to the published version of the manuscript.

Funding: This research was funded by the Centre National de la Recherche Scientifique (CNRS), Institut National de la Santé et de la Recherche Médicale (INSERM), Université Clermont Auvergne (UCA), by ANR grants 'Dynam'Het' ANR-11 JSV2 00901 and 'SINUDYN' ANR-12 ISV6 0001, by ISV6 000116-IDEX-0001 CAP 20-25 challenge 1 and the Pack Ambition Recherche project Noyau-HD from the Region Auvergne Rhone-Alpes.

Data Availability Statement: The data presented in this study are available on request from the corresponding author.

Acknowledgments: S.C., S.D., C.T. and A.V.P. acknowledge support from the CLIC (CLermont Imagerie Confocale) microscopy platform and networking support from the COST Action INDEPTH (CA16212).

Conflicts of Interest: The authors declare no conflict of interest. The funders had no role in the design of the study; in the collection, analyses, or interpretation of data; in the writing of the manuscript, or in the decision to publish the results.

\section{References}

1. Bewley, J.D. Seed Germination and Dormancy. Plant Cell 1997, 9, 1055-1066. [CrossRef]

2. Saux, M.; Bleys, B.; André, T.; Bailly, C. A Correlative Study of Sunflower Seed Vigor Components as Related to Genetic Background. Plants 2020, 9, 386. [CrossRef]

3. Finch-Savage, W.E.; Bassel, G.W. Seed vigour and crop establishment: Extending performance beyond adaptation. J. Exp. Bot. 2016, 67, 567-591. [CrossRef]

4. Klupczyńska, E.A.; Pawłowski, T.A. Regulation of Seed Dormancy and Germination Mechanisms in a Changing Environment. Int. J. Mol. Sci. 2021, 22, 1357. [CrossRef] [PubMed]

5. Finch-Savage, W.E.; Leubner-Metzger, G. Seed dormancy and the control of germination. New Phytol. 2006, 171, 501-523. [CrossRef]

6. Finkelstein, R.; Reeves, W.; Ariizumi, T.; Steber, C. Molecular aspects of seed dormancy. Annu. Rev. Plant Biol. 2008, 59, 387-415. [CrossRef]

7. Bentsink, L.; Jowett, J.; Hanhart, C.J.; Koornneef, M. Cloning of DOG1, a quantitative trait locus controlling seed dormancy in Arabidopsis. Proc. Natl. Acad. Sci. USA 2006, 103, 17042-17047. [CrossRef]

8. van Zanten, M.; Tessadori, F.; Peeters, A.J.; Fransz, P. Shedding Light on Large-Scale Chromatin Reorganization in Arabidopsis thaliana. Mol. Plant 2012, 5, 583-590. [CrossRef] [PubMed] 
9. Benoit, M.; Simon, L.; Desset, S.; Duc, C.; Cotterell, S.; Poulet, A.; Le Goff, S.; Tatout, C.; Probst, A.V. Replication-coupled histone H3.1 deposition determines nucleosome composition and heterochromatin dynamics during Arabidopsis seedling development. New Phytol. 2019, 221, 385-398. [CrossRef] [PubMed]

10. Basbouss-Serhal, I.; Soubigou-Taconnat, L.; Bailly, C.; Leymarie, J. Germination Potential of Dormant and Nondormant Arabidopsis Seeds Is Driven by Distinct Recruitment of Messenger RNAs to Polysomes. Plant Physiol. 2015, 168, 1049-1065. [CrossRef]

11. Basbouss-Serhal, I.; Pateyron, S.; Leymarie, J.; Cochet, F.; Bailly, C. $5^{\prime}$ to $3^{\prime}$ mRNA decay contributes to the regulation of Arabidopsis seed germination by dormancy. Plant Physiol. 2017, 173. [CrossRef]

12. Müller, K.; Bouyer, D.; Schnittger, A.; Kermode, A.R. Evolutionarily Conserved Histone Methylation Dynamics during Seed Life-Cycle Transitions. PLoS ONE 2012, 7, e51532. [CrossRef] [PubMed]

13. Nonogaki, H. Seed dormancy and germination-Emerging mechanisms and new hypotheses. Front. Plant Sci. 2014, 5, 1-14. [CrossRef]

14. Luger, K.; Mäder, A.; Richmond, R. Crystal structure of the nucleosome core particle at 2.8 A resolution. Nature 1997, 389, 251-260 [CrossRef] [PubMed]

15. Tessarz, P.; Kouzarides, T. Histone core modifications regulating nucleosome structure and dynamics. Nat. Rev. Mol. Cell Biol. 2014, 15, 703-708. [CrossRef] [PubMed]

16. Probst, A.V.; Desvoyes, B.; Gutierrez, C. Similar yet Critically Different: The distribution, dynamics and function of Histone Variants. J. Exp. Bot. 2020, 71, 5191-5204. [CrossRef] [PubMed]

17. Roudier, F.; Ahmed, I.; Bérard, C.; Sarazin, A.; Mary-Huard, T.; Cortijo, S.; Bouyer, D.; Caillieux, E.; Duvernois-Berthet, E.; Al-Shikhley, L.; et al. Integrative epigenomic mapping defines four main chromatin states in Arabidopsis. EMBO J. 2011, 30, 1928-1938. [CrossRef]

18. Sequeira-Mendes, J.; Aragüez, I.; Peiró, R.; Mendez-Giraldez, R.; Zhang, X.; Jacobsen, S.E.; Bastolla, U.; Gutierrez, C. The Functional Topography of the Arabidopsis Genome Is Organized in a Reduced Number of Linear Motifs of Chromatin States. Plant Cell 2014, 26, 2351-2366. [CrossRef]

19. Zheng, J.; Chen, F.; Wang, Z.; Cao, H.; Li, X.; Deng, X.; Soppe, W.J.; Li, Y.; Liu, Y. A novel role for histone methyltransferase KYP/SUVH4 in the control of Arabidopsis primary seed dormancy. New Phytol. 2011, 193, 605-616. [CrossRef]

20. van Zanten, M.; Zöll, C.; Wang, Z.; Philipp, C.; Carles, A.; Li, Y.; Kornet, N.G.; Liu, Y.; Soppe, W.J.J. HISTONE DEACETYLASE 9 represses seedling traits in Arabidopsis thaliana dry seeds. Plant J. 2014, 475-488. [CrossRef]

21. Tanaka, M.; Kikuchi, A.; Kamada, H. The Arabidopsis histone deacetylases HDA6 and HDA19 contribute to the repression of embryonic properties after germination. Plant Physiol. 2008, 146, 149-161. [CrossRef]

22. Liu, Y.; Koornneef, M.; Soppe, W.J.J. The Absence of Histone H2B Monoubiquitination in the Arabidopsis hub1 (rdo4) Mutant Reveals a Role for Chromatin Remodeling in Seed Dormancy. Plant Cell 2007, 19, 433-444. [CrossRef] [PubMed]

23. Krajewski, W.A.; Li, J.; Dou, Y. Effects of histone H2B ubiquitylation on the nucleosome structure and dynamics. Nucleic Acids Res. 2018, 46, 7631-7642. [CrossRef] [PubMed]

24. Pavri, R.; Zhu, B.; Li, G.; Trojer, P.; Mandal, S.; Shilatifard, A.; Reinberg, D. Histone H2B Monoubiquitination Functions Cooperatively with FACT to Regulate Elongation by RNA Polymerase II. Cell 2006, 125, 703-717. [CrossRef] [PubMed]

25. Fleming, A.B.; Kao, C.-F.; Hillyer, C.; Pikaart, M.; Osley, M.A. H2B Ubiquitylation Plays a Role in Nucleosome Dynamics during Transcription Elongation. Mol. Cell 2008, 31, 57-66. [CrossRef] [PubMed]

26. Mortensen, S.A.; Grasser, K.D. The seed dormancy defect of Arabidopsis mutants lacking the transcript elongation factor TFIIS is caused by reduced expression of the DOG1 gene. FEBS Lett. 2014, 588, 47-51. [CrossRef]

27. Grasser, M.; Kane, C.M.; Merkle, T.; Melzer, M.; Emmersen, J.; Grasser, K.D. Transcript Elongation Factor TFIIS Is Involved in Arabidopsis Seed Dormancy. J. Mol. Biol. 2009, 386, 598-611. [CrossRef]

28. Antosz, W.; Pfab, A.; Ehrnsberger, H.F.; Holzinger, P.; Köllen, K.; Mortensen, S.A.; Bruckmann, A.; Schubert, T.; Längst, G.; Griesenbeck, J.; et al. The Composition of the Arabidopsis RNA Polymerase II Transcript Elongation Complex Reveals the Interplay between Elongation and mRNA Processing Factors. Plant Cell 2017, 29, 854-870. [CrossRef]

29. Jin, C.; Felsenfeld, G. Nucleosome stability mediated by histone variants H3.3 and H2A.Z. Genes Dev. 2007, 21, 1519-1529. [CrossRef]

30. Stroud, H.; Otero, S.; Desvoyes, B.; Ramírez-Parra, E.; Jacobsen, S.E.; Gutierrez, C. Genome-wide analysis of histone H3.1 and H3.3 variants in Arabidopsis thaliana. Proc. Natl. Acad. Sci. USA 2012, 109, 5370-5375. [CrossRef]

31. Wollmann, H.; Holec, S.; Alden, K.; Clarke, N.; Jacques, P.; Berger, F. Dynamic deposition of histone variant H3.3 accompanies developmental remodeling of the Arabidopsis transcriptome. PLoS Genet. 2012, 8, e1002658. [CrossRef]

32. Duc, C.; Benoit, M.; Détourné, G.; SIMON, L.; Poulet, A.; Jung, M.; Veluchamy, A.; Latrasse, D.; Le Goff, S.; Cotterell, S.; et al. Arabidopsis ATRX Modulates H3.3 Occupancy and Fine-Tunes Gene Expression. Plant Cell 2017, 29, 1773-1793. [CrossRef]

33. Hammond, C.M.; Strømme, C.B.; Huang, H.; Patel, D.J.; Groth, A. Histone chaperone networks shaping chromatin function. Nat. Rev. Mol. Cell Biol. 2017, 18, 141-158. [CrossRef]

34. Tagami, H.; Ray-Gallet, D.; Almouzni, G.; Nakatani, Y. Histone H3.1 and H3.3 complexes mediate nucleosome assembly pathways dependent or independent of DNA synthesis. Cell 2004, 116, 51-61. [CrossRef]

35. Kaufman, P.D.; Kobayashi, R.; Kessler, N.; Stillman, B. The p150 and p60 Subunits of Chromatin Assembly Factor I: A Molecular Link between Newly Synthesized Histones and DNA Replication. Cell 1995, 81, 1105-1114. [CrossRef] 
36. Kaya, H.; Shibahara, K.I.; Taoka, K.I.; Iwabuchi, M.; Stillman, B.; Araki, T. FASCIATA genes for chromatin assembly factor-1 in arabidopsis maintain the cellular organization of apical meristems. Cell 2001, 104, 131-142. [CrossRef]

37. Shibahara, K.; Stillman, B. Replication-dependent marking of DNA by PCNA facilitates CAF-1-coupled inheritance of chromatin. Cell 1999, 96, 575-585. [CrossRef]

38. Jiang, D.; Berger, F. DNA replication-coupled histone modification maintains Polycomb gene silencing in plants. Science 2017, 357, 1146-1149. [CrossRef]

39. Polo, S.E.; Roche, D.; Almouzni, G. New histone incorporation marks sites of UV repair in human cells. Cell 2006, 127, 481-493. [CrossRef] [PubMed]

40. Goldberg, A.D.; Banaszynski, L.A.; Noh, K.M.; Lewis, P.W.; Elsaesser, S.J.; Stadler, S.; Dewell, S.; Law, M.; Guo, X.; Li, X.; et al Distinct factors control histone variant H3.3 localization at specific genomic regions. Cell 2010, 140, 678-691. [CrossRef] [PubMed]

41. Ray-Gallet, D.; Quivy, J.P.; Scamps, C.; Martini, E.M.; Lipinski, M.; Almouzni, G. HIRA is critical for a nucleosome assembly pathway independent of DNA synthesis. Mol. Cell 2002, 9, 1091-1100. [CrossRef]

42. Nie, X.; Wang, H.; Li, J.; Holec, S.; Berger, F. The HIRA complex that deposits the histone H3.3 is conserved in Arabidopsis and facilitates transcriptional dynamics. Biol. Open 2014, 3, 794-802. [CrossRef]

43. Duc, C.; Benoit, M.; Goff, S.L.; Simon, L.; Poulet, A.; Cotterell, S.; Tatout, C.; Probst, A.V. The histone chaperone complex HIR maintains nucleosome occupancy and counterbalances impaired histone deposition in CAF-1 complex mutants. Plant J. 2015, 81, 707-722. [CrossRef] [PubMed]

44. Torné, J.; Ray-Gallet, D.; Boyarchuk, E.; Garnier, M.; Le Baccon, P.; Coulon, A.; Orsi, G.A.; Almouzni, G. Two HIRA-dependent pathways mediate H3.3 de novo deposition and recycling during transcription. Nat. Struct. Mol. Biol. 2020, 27, 1057-1068. [CrossRef] [PubMed]

45. Shu, H.; Nakamura, M.; Siretskiy, A.; Borghi, L.; Moraes, I.; Wildhaber, T.; Gruissem, W.; Hennig, L. Arabidopsis replacement histone variant H3.3 occupies promoters of regulated genes. Genome Biol. 2014, 15, R62. [CrossRef] [PubMed]

46. Ingouff, M.; Rademacher, S.; Holec, S.; Soljić, L.; Xin, N.; Readshaw, A.; Foo, S.H.; Lahouze, B.; Sprunck, S.; Berger, F. Zygotic Resetting of the HISTONE 3 Variant Repertoire Participates in Epigenetic Reprogramming in Arabidopsis. Curr. Biol. 2010, 20, 2137-2143. [CrossRef]

47. Borg, M.; Jacob, Y.; Susaki, D.; Leblanc, C.; Buendía, D.; Axelsson, E.; Kawashima, T.; Voigt, P.; Boavida, L.; Becker, J.; et al. Targeted reprogramming of H3K27me3 resets epigenetic memory in plant paternal chromatin. Nat. Cell Biol. 2020, 22, 621-629. [CrossRef] [PubMed]

48. Otero, S.; Desvoyes, B.; Peiró, R.; Gutierrez, C. Histone H3 Dynamics Reveal Domains with Distinct Proliferation Potential in the Arabidopsis Root. Plant Cell 2016, 28, 1361-1371. [CrossRef] [PubMed]

49. Kawakatsu, T.; Nery, J.R.; Castanon, R.; Ecker, J.R. Dynamic DNA methylation reconfiguration during seed development and germination. Genome Biol. 2017, 18, 171. [CrossRef] [PubMed]

50. Shi, L.; Wang, J.; Hong, F.; Spector, D.L.; Fang, Y. Four amino acids guide the assembly or disassembly of Arabidopsis histone H3.3-containing nucleosomes. Proc. Natl. Acad. Sci. USA 2011, 108, 10574-10578. [CrossRef]

51. Finkelstein, R.R.; Gampala, S.S.L.; Rock, C.D. Abscisic acid signaling in seeds and seedlings. Plant Cell 2002, 14 (Suppl 1.), S15-S45. [CrossRef]

52. Bourbousse, C.; Ahmed, I.; Roudier, F.; Zabulon, G.; Blondet, E.; Balzergue, S.; Colot, V.; Bowler, C.; Barneche, F. Histone H2B Monoubiquitination Facilitates the Rapid Modulation of Gene Expression during Arabidopsis Photomorphogenesis. PLoS Genet. 2012, 8, e1002825. [CrossRef]

53. Liu, Y.; Geyer, R.; van Zanten, M.; Carles, A.; Li, Y.; Hörold, A.; van Nocker, S.; Soppe, W.J.J. Identification of the Arabidopsis REDUCED DORMANCY 2 Gene Uncovers a Role for the Polymerase Associated Factor 1 Complex in Seed Dormancy. PLoS ONE 2011, 6, e22241. [CrossRef]

54. Claeys, H.; Landeghem, V.; Dubois, M.; Maleux, K.; Inzé, D. What Is Stress? Dose-Response Effects in Commonly Used in Vitro Stress Assays. Plant Physiol. 2014, 165, 519-527. [CrossRef]

55. Desvoyes, B.; Arana-Echarri, A.; Barea, M.D.; Gutierrez, C. A comprehensive fluorescent sensor for spatiotemporal cell cycle analysis in Arabidopsis. Nat. Plants 2020, 6, 1330-1334. [CrossRef]

56. Bewley, J.D.; Black, M. Seeds: Physiology of Development and Germination; Plenum Press: New York, NY, USA, 1994.

57. Barrôco, R.M.; Van Poucke, K.; Bergervoet, J.H.W.; De Veylder, L.; Groot, S.P.C.; Inzé, D.; Engler, G. The role of the cell cycle machinery in resumption of postembryonic development. Plant Physiol. 2005, 137, 127-140. [CrossRef]

58. Jiang, D.; Borg, M.; Lorković, Z.J.; Montgomery, S.A.; Osakabe, A.; Yelagandula, R.; Axelsson, E.; Berger, F. The evolution and functional divergence of the histone H2B family in plants. PLoS Genet. 2020, 16, e1008964. [CrossRef]

59. Khadka, J.; Pesok, A.; Grafi, G. Plant Histone HTB (H2B) Variants in Regulating Chromatin Structure and Function. Plants 2020, 9 , 1435. [CrossRef] [PubMed]

60. van Zanten, M.; Koini, M.A.; Geyer, R.; Liu, Y.; Brambilla, V.; Bartels, D.; Koornneef, M.; Fransz, P.; Soppe, W.J. Seed maturation in Arabidopsis thaliana is characterized by nuclear size reduction and increased chromatin condensation. Proc. Natl. Acad. Sci. USA 2011, 108, 20219-20224. [CrossRef]

61. Molitor, A.M.; Bu, Z.; Yu, Y.; Shen, W.-H. Arabidopsis AL PHD-PRC1 Complexes Promote Seed Germination through H3K4me3to-H3K27me3 Chromatin State Switch in Repression of Seed Developmental Genes. PLoS Genet. 2014, 10, e1004091. [CrossRef] 
62. Johnson, L.; Mollah, S.; Garcia, B.A.; Muratore, T.L.; Shabanowitz, J.; Hunt, D.F.; Jacobsen, S.E. Mass spectrometry analysis of Arabidopsis histone H3 reveals distinct combinations of post-translational modifications. Nucleic Acids Res. 2004, 32, $6511-6518$. [CrossRef]

63. Masubelele, N.H.; Dewitte, W.; Menges, M.; Maughan, S.; Collins, C.; Huntley, R.; Nieuwland, J.; Scofield, S.; Murray, J.A. D-type cyclins activate division in the root apex to promote seed germination in Arabidopsis. Proc. Natl. Acad. Sci. USA 2005, 102, 15694-15699. [CrossRef] [PubMed]

64. Narsai, R.; Gouil, Q.; Secco, D.; Srivastava, A.; Karpievitch, Y.V.; Liew, L.C.; Lister, R.; Lewsey, M.G.; Whelan, J. Extensive transcriptomic and epigenomic remodelling occurs during Arabidopsis thaliana germination. Genome Biol. 2017, 18, 172. [CrossRef]

65. Ray-Gallet, D.; Woolfe, A.; Vassias, I.; Pellentz, C.; Lacoste, N.; Puri, A.; Schultz, D.C.; Pchelintsev, N.A.; Adams, P.D.; Jansen, L.E.; et al. Dynamics of histone $\mathrm{H} 3$ deposition in vivo reveal a nucleosome gap-filling mechanism for H3.3 to maintain chromatin integrity. Mol. Cell 2011, 44, 928-941. [CrossRef]

66. Michl-Holzinger, P.; Mortensen, S.A.; Grasser, K.D. The SSRP1 subunit of the histone chaperone FACT is required for seed dormancy in Arabidopsis. J. Plant Physiol. 2019, 236, 105-108. [CrossRef] [PubMed]

67. Jeronimo, C.; Poitras, C.; Robert, F. Histone Recycling by FACT and Spt6 during Transcription Prevents the Scrambling of Histone Modifications. Cell Rep. 2019, 28, 1206-1218. [CrossRef]

68. Saldi, T.; Cortazar, M.A.; Sheridan, R.M.; Bentley, D.L. Coupling of RNA Polymerase II Transcription Elongation with Pre-mRNA Splicing. J. Mol. Biol. 2016, 428, 2623-2635. [CrossRef]

69. Shu, K.; Liu, X.-D.; Xie, Q.; He, Z.-H. Two Faces of One Seed: Hormonal Regulation of Dormancy and Germination. Mol. Plant 2016, 9, 34-45. [CrossRef]

70. Bailly, C. Active oxygen species and antioxidants in seed biology. Seed Sci. Res. 2004, 14, 93-107. [CrossRef]

71. Adam, S.; Polo, S.E.; Almouzni, G. Transcription Recovery after DNA Damage Requires Chromatin Priming by the H3.3 Histone Chaperone HIRA. Cell 2013, 155, 94-106. [CrossRef]

72. Ray-Gallet, D.; Ricketts, M.D.; Sato, Y.; Gupta, K.; Boyarchuk, E.; Senda, T.; Marmorstein, R.; Almouzni, G. Functional activity of the H3.3 histone chaperone complex HIRA requires trimerization of the HIRA subunit. Nat. Commun. 2018, 9, 3103. [CrossRef]

73. Rajjou, L.; Gallardo, K.; Debeaujon, I.; Vandekerckhove, J.; Job, C.; Job, D. The effect of alpha-amanitin on the Arabidopsis seed proteome highlights the distinct roles of stored and neosynthesized mRNAs during germination. Plant Physiol. 2004, 134, 1598-1613. [CrossRef] [PubMed]

74. Holdsworth, M.J.; Finch-Savage, W.E.; Grappin, P.; Job, D. Post-genomics dissection of seed dormancy and germination. Trends Plant Sci. 2008, 13, 7-13. [CrossRef]

75. Rajjou, L.; Lovigny, Y.; Groot, S.P.C.; Belghazi, M.; Job, C.; Job, D. Proteome-wide characterization of seed aging in Arabidopsis: A comparison between artificial and natural aging protocols. Plant Physiol. 2008, 148, 620-641. [CrossRef]

76. Waterworth, W.M.; Bray, C.M.; West, C.E. The importance of safeguarding genome integrity in germination and seed longevity. J. Exp. Bot. 2015, 66, 3549-3558. [CrossRef] [PubMed]

77. Waterworth, W.M.; Masnavi, G.; Bhardwaj, R.M.; Jiang, Q.; Bray, C.M.; West, C.E. A plant DNA ligase is an important determinant of seed longevity. Plant J. 2010, 63, 848-860. [CrossRef] [PubMed]

78. Li, X.; Tyler, J.K. Nucleosome disassembly during human non-homologous end joining followed by concerted HIRA- and CAF-1-dependent reassembly. eLife 2016, 5, 1-18. [CrossRef] [PubMed]

79. Zhang, W.; Cochet, F.; Ponnaiah, M.; Lebreton, S.; Matheron, L.; Pionneau, C.; Boudsocq, M.; Resentini, F.; Huguet, S.; Blázquez, M.Á.; et al. The MPK8-TCP14 pathway promotes seed germination in Arabidopsis. Plant J. 2019, 100, 677-692. [CrossRef]

80. Czechowski, T.; Stitt, M.; Altmann, T.; Udvardi, M.K.; Scheible, W.R. Genome-wide identification and testing of superior reference genes for transcript normalization in Arabidopsis. Plant Physiol. 2005, 139, 5-17. [CrossRef]

81. Jurdak, R.; Launay-Avon, A.; Paysant-Le Roux, C.; Bailly, C. Retrograde signalling from the mitochondria to the nucleus translates the positive effect of ethylene on dormancy breaking of Arabidopsis thaliana seeds. New Phytol. 2021, 229, 2192-2205. [CrossRef] 